\title{
Good syndrome, bad problem
}

\section{Bianca Martinez and Sarah K. Browne*}

Immunopathogenesis Section, Laboratory of Clinical Infectious Diseases, National Institute of Allergy and Infectious Diseases, National Institutes of Health, Bethesda, MD, USA

${ }^{*}$ Correspondence: brownesa@niaid.nih.gov

Edited by:

Arun Rajan, National Cancer Institute, USA

Reviewed by:

Ronan Kelly, Johns Hopkins, USA

Keywords: thymoma, adult-onset immunodeficiency, thymic neoplasia, anti-cytokine autoantibodies, opportunistic infection

\section{A commentary on}

Three difficult cases: the challenge of autoimmunity, immunodeficiency and recurrent infections in patients with Good's syndrome

by Arnold SJ, Hodgson T, Misbah SA, Patel SY, Cooper SM, Venning VA. Br J Dermatol (2014). doi:10.1111/bjd.13293

Good syndrome (GS), which is classically defined as the triad of thymoma, immunodeficiency, and hypogammaglobulinemia, was first characterized by Robert Alan Good, a pioneer in the field of immunodeficiency diseases, who recognized the crucial role that the thymus plays in the development of the immune system (1). The definition of this entity remains vague, in part because of the protean immunological manifestations of thymic epithelial neoplasms. How the thymus influences the precise balance of immune reactivity that is so critical to both hostdefense and self-tolerance remains to be fully understood. Accordingly, immunologic manifestations because of thymic epithelial tumors can range from nothing to severe autoimmunity, immunodeficiency, or both, the spectrum of which is broad and patient-specific (Table 1). Further, patients may have opportunistic infection without gross immunologic lab abnormalities (2), and conversely, may have relatively few problems, despite an abnormal immune profile (3). Nevertheless, we can look to the immunology and infectious complications in individual patients, to identify where their immune defects are most concentrated and how to go about treating them.
The critical role that the thymus plays in $\mathrm{T}$ cell education likely explains the observation of coincident autoimmunity and immunodeficiency in thymoma, reflecting $\mathrm{T}$ cells that are both over-reactive to self and under-responsive to pathogens. The importance of the $\mathrm{T}$ cell in directing $\mathrm{B}$ cell responses is also apparent in the immunopathology of thymoma. Consistent with $\mathrm{T}$ cell immunodeficiency, patients with thymoma can develop pneumocystis pneumonia, cytomegalovirus, mucocutaneous candidiasis, varicella zoster reactivation (both localized and systemic), Kaposi's sarcoma, and progressive multifocal leukoencephalopathy, cryptococcosis, and nontuberculous mycobacteria $(2,4,5)$. Underscoring the $\mathrm{B}$ cell component of this disease, the cardinal manifestation of GS is hypogammaglobulinemia. In fact, the most prominent clinical characteristics of GS includes an increased susceptibility to sinopulmonary bacterial infections with encapsulated organisms (Haemophilus influenza and Streptococcus pneumonia), which is clearly associated with hypogammaglobulinemia. Even outside classical GS, a tendency toward B cell dysfunction is apparent in the observation that anti-acetylcholine receptor autoantibody-associated myasthenia gravis is the most frequent autoimmune complication of thymoma (6). B cell lymphopenia is also common and in some cases has even led to the initial diagnosis of thymoma (7, Allergy and Asthma Proceedings). Together, these observations underscore the complex interrelatedness of $\mathrm{T}$ and $\mathrm{B}$ lymphocyte biology.
Another potential mechanism of infection susceptibility is presence of anticytokine autoantibodies $(2,8-10)$. It is clear that anti-cytokine autoantibodies are an important and emerging mechanisms of adult-onset immunodeficiency (11) and can be responsible for severe opportunistic infection in previously healthy adults $(12,13)$. Interestingly, mucocutaneous candidiasis has been seen in association with anti-IL-17 and anti-IL-22 autoantibodies in autoimmune polyendocrinopathy candidiasis ectodermal dystrophy (APECED) syndrome $(14,15)$, caused by a Mendelian deficiency of the autoimmune regulator (AIRE) gene. AIRE is critical for the negative selection of autoreactive $\mathrm{T}$ cells in the thymus (16) and likely explains much of the profound and diverse autoimmune phenomena that are typical of APECED. This compelling link between autoimmunity and immunodeficiency may also be relevant to thymoma where defective AIRE expression has been recognized (17), as has a predisposition to mucocutaneous candidiasis in association with anti-IL-17 and IL-22 autoantibodies $(2,14)$.

Immunological evaluation can include an assessment of quantitative immunoglobulins, as well as B and T lymphocyte subsets. If the clinical presentation points to antibody deficiency, a vaccine challenge may help evaluate the patient's ability to generate an appropriate humoral response, which can be impaired even with relatively normal IgG levels. Testing for anti-cytokine autoantibodies is done in specialized laboratories on a research basis.

Treatment of infection generally focuses on targeted antimicrobial therapy. In the case of recurrent sinopulmonary infections 
Table 1 | Immunologic abnormalities reported in thymoma

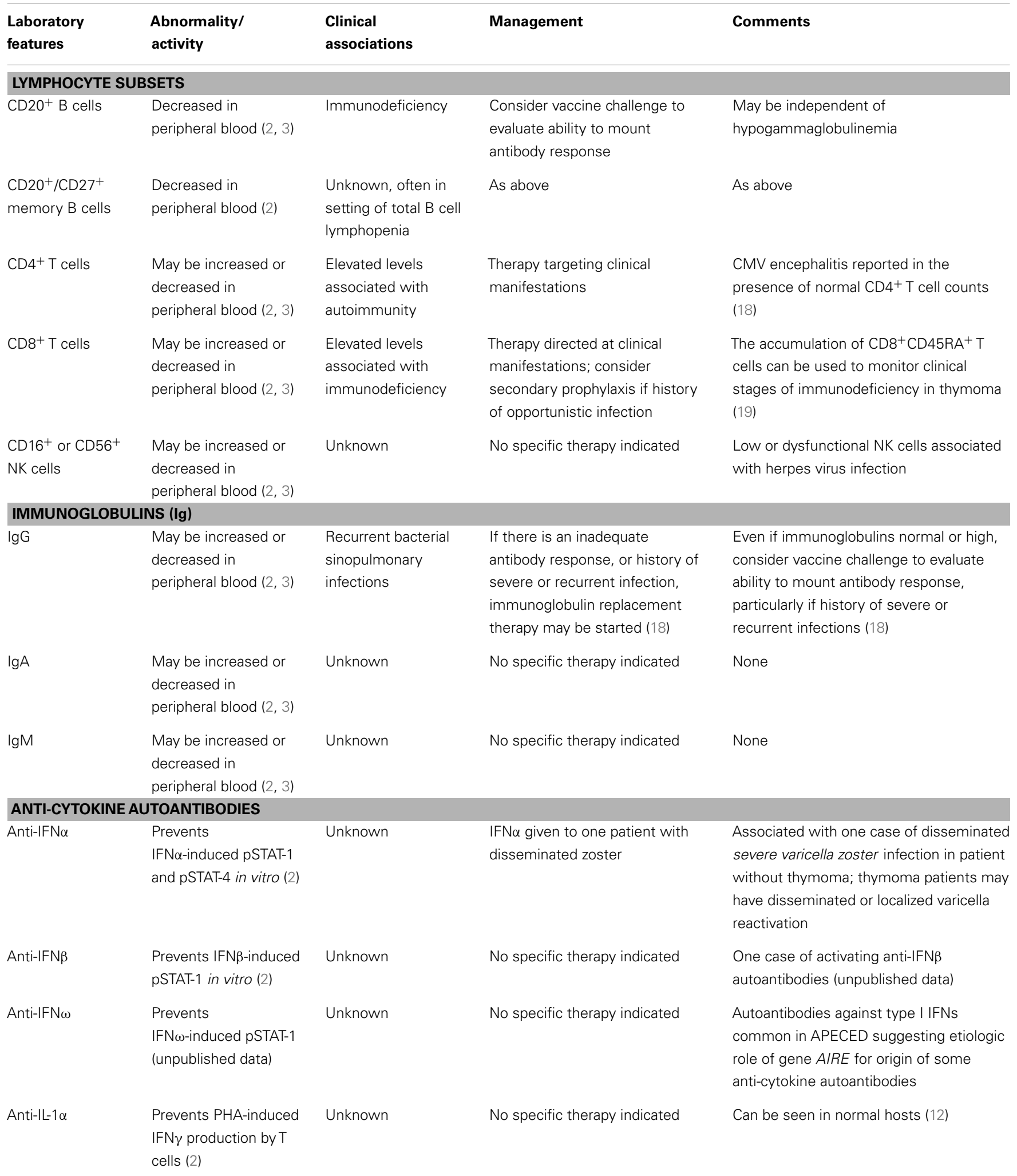


Table 1 | Continued

\begin{tabular}{|c|c|c|c|c|}
\hline $\begin{array}{l}\text { Laboratory } \\
\text { features }\end{array}$ & $\begin{array}{l}\text { Abnormality/ } \\
\text { activity }\end{array}$ & $\begin{array}{l}\text { Clinical } \\
\text { associations }\end{array}$ & Management & Comments \\
\hline Anti-IL-12p70 & $\begin{array}{l}\text { Prevents IL-12-induced } \\
\text { pSTAT-4 in vitro; } \\
\text { prevented } \\
\text { IL-12-induced IFN } \gamma \\
\text { in vitro (2) }\end{array}$ & Unknown & Targeted anti-infectives & $\begin{array}{l}\text { Associated with one case of disseminated } \\
\text { Burkholderia gladioli infection in patient } \\
\text { without thymoma }\end{array}$ \\
\hline Anti-12p35 & $\begin{array}{l}\text { Same as effects seen } \\
\text { with anti-IL-12p70 } \\
\text { autoantibodies }\end{array}$ & Unknown & No specific therapy indicated & None \\
\hline Anti-IL-12p40 & $\begin{array}{l}\text { Same as effects seen } \\
\text { with anti-IL-12p70 }\end{array}$ & Unknown & No specific therapy indicated & $\begin{array}{l}\text { The } \mathrm{p} 40 \text { subunit is common to } \mathrm{IL}-23 \text {, } \\
\text { raising possibility for activity beyond } \\
\text { neutralization of IL-12 }\end{array}$ \\
\hline $\begin{array}{l}\text { IL-17A or } \\
\text { anti-IL-17F }\end{array}$ & $\begin{array}{l}\text { Prevents IL-17-induced } \\
\text { IL-6 production in HFF } \\
\text { cells (2) }\end{array}$ & CMC (14) & Topical or systemic antifungals & $\begin{array}{l}\text { Associated with CMC in APECED } \\
\text { syndrome (14); may become } \\
\text { treatment-refractory }\end{array}$ \\
\hline IL-22 & Not assessed & CMC (14) & Topical or systemic antifungals & $\begin{array}{l}\text { Associated with CMC in APECED } \\
\text { syndrome; IL-22+/IL-17- cells protect } \\
\text { epithelial surfaces and show skin-homing } \\
\text { properties, which may explain the } \\
\text { mucocutaneous focus of the } \\
\text { candidiasis (14) }\end{array}$ \\
\hline $\mathrm{TNF} \alpha$ & Not assessed (2) & Unknown & Unknown & Unknown \\
\hline
\end{tabular}

NK, natural killer; IFN, interferon; APECED, autoimmune polyendocrinopathy candidiasis ectodermal dystrophy; AIRE, autoimmune regulator; IL, interleukin; CMC, chronic mucocutaneous candidiasis; TNF , tumor necrosis factor alpha.

associated with hypogammaglobulinemia, intravenous immunoglobulin (IVIg) can be an effective prophylactic measure. IVIg has also been used to augment the immune response in the case of $\mathrm{CMV}$ infection (5). It can also be effective in treating anti-acetylcholine receptor-associated myasthenia gravis, although the mechanistic explanation for this benefit remains elusive. Secondary prophylaxis could be considered in patients under certain circumstances such as those who have had pneumocystis pneumonia.

A better understanding of the underlying immunological defects in thymoma will enhance therapeutic options, such as primary prophylaxis or immunomodulation. Furthermore, despite the focality of their primary immunologic lesion (the neoplastic thymic epithelial cells), patients with thymoma can demonstrate fascinating clinical overlaps with many other diseases, from rheumatologic, hematologic, and pulmonary disorders, to primary and congenital immunodeficiency, and far beyond. Thus, understanding thymoma, as Dr. Good so astutely recognized in decades past, will provide an important opportunity that should not be missed, to improve care of these complex patients, and to shed light on fundamental principals of human immunology.

\section{ACKNOWLEDGMENTS}

This work was supported by the Division of Intramural Research, National Institute of Allergy and Infectious Diseases, National Institutes of Health.

\section{REFERENCES}

1. Good RA, Varco RL. A clinical and experimental study of agammaglobulinemia. J Lancet (1955) 75:245-71.

2. Burbelo PD, Browne SK, Sampaio EP, Giaccone G, Zaman R, Kristosturyan E, et al. Anti-cytokine autoantibodies are associated with opportunistic infection in patients with thymic neoplasia. Blood (2010) 116:4848-58. doi:10.1182/blood-2010-05286161

3. Khawaja MR, Nelson RP Jr, Miller N, Badve SS, Loehrer E, Czader $\mathrm{M}$, et al. Immune- mediated diseases and immunodeficiencies associated with thymic epithelial neoplasms. J Clin Immunol (2012) 32:430-7. doi:10.1007/s10875011-9644-1

4. Squintani G, Ferrari S, Bazzoli E, Eleopra R, La Monaca C, Cagliari E, et al. Progressive multifocal leukoencephalopathy in a patient with Good's syndrome. Int J Infect Dis (2010) 14:e444-7. doi: 10.1016/j.ijid.2009.06.005

5. Tarr PE, Sneller MC, Mechanic LJ, Economides A, Eger CM, Strober W, et al. Infections in patients with immunodeficiency with thymoma (Good syndrome). Report of 5 cases and review of the literature. Medicine (Baltimore) (2001) 80:123-33. doi:10.1097/00005792-200103000-00005

6. Tormoehlen LM, Pascuzzi RM. Thymoma, myasthenia gravis, and other paraneoplastic syndromes. Hematol Oncol Clin North Am (2008) 22:509-26. doi:10.1016/j.hoc.2008.03.004

7. Kennedy JL, Schroeder N, Palacios T, Rosen LB, Martinez B, Browne S, et al. Fifty-five-year-old man with chronic yeast infections. Allergy Asthma Proc. (2014) 35(5):415-22. doi:10.2500/aap.2014. 35.3776

8. Meager A, Vincent A, Newsom-Davis J, Will$\operatorname{cox}$ N. Spontaneous neutralising antibodies to interferon - alpha and interleukin-12 in thymoma-associated autoimmune disease. Lancet (1997) 350:1596-7. doi:10.1016/S0140-6736(05) 64012-3 
9. Meager A, Wadhwa M, Dilger P, Bird C, Thorpe R, Newsom-Davis J, et al. Anti-cytokine autoantibodies in autoimmunity: preponderance of neutralizing autoantibodies against interferon-alpha, interferon-omega and interleukin-12 in patients with thymoma and/or myasthenia gravis. Clin Exp Immunol (2003) 132:128-36. doi:10.1046/j.13652249.2003.02113.x

10. Rajan A, Carter CA, Berman A, Cao L, Kelly RJ, Thomas A, et al. Cixutumumab for patients with recurrent or refractory advanced thymic epithelial tumours: a multicentre, open-label, phase 2 trial. Lancet Oncol (2014) 15:191-200. doi:10. 1016/S1470-2045(13)70596-5

11. Browne SK. Anticytokine autoantibody-associated immunodeficiency. Annu Rev Immunol (2014) 32:635-57. doi:10.1146/annurev-immunol032713-120222

12. Browne SK, Burbelo PD, Chetchotisakd P, Suputtamongkol Y, Kiertiburanakul S, Shaw PA, et al. Adult-onset immunodeficiency in Thailand and Taiwan. N Engl J Med (2012) 367:725-34. doi:10. 1056/NEJMoal111160

13. Rosen LB, Freeman AF, Yang LM, Jutivorakool $\mathrm{K}$, Olivier KN, Angkasekwinai N, et al. Anti-GMCSF autoantibodies in patients with cryptococcal meningitis. J Immunol (2013) 190:3959-66. doi:10.4049/jimmunol.1202526
14. Kisand K, Bøe Wolff AS, Podkrajsek KT, Tserel L, Link M, Kisand KV, et al. Chronic mucocutaneous candidiasis in APECED or thymoma patients correlates with autoimmunity to Th17-associated cytokines. J Exp Med (2010) 207:299-308. doi:10. 1084/jem.20091669

15. Puel A, Döffinger R, Natividad A, Chrabieh M, Barcenas-Morales G, Picard C, et al. Autoantibodies against IL-17A, IL-17F, and IL-22 in patients with chronic mucocutaneous candidiasis and autoimmune polyendocrine syndrome type I. J Exp Med (2010) 207:291-7. doi:10.1084/jem. 20091983

16. Anderson MS, Venanzi ES, Klein L, Chen Z, Berzins SP, Turley SJ, et al. Projection of an immunological self shadow within the thymus by the aire protein. Science (2002) 298:1395-401. doi:10.1126/science. 1075958

17. Ströbel P, Murumägi A, Klein R, Luster M, Lahti M, Krohn K, et al. Deficiency of the autoimmune regulator AIRE in thymomas is insufficient to elicit autoimmune polyendocrinopathy syndrome type 1 (APS-1). J Pathol (2007) 211:563-71. doi:10. 1002/path.2141

18. Kelleher P, Misbah SA. What is Good's syndrome? Immunological abnormalities in patients with thymoma. J Clin Pathol (2003) 56:12-6. doi:10.1136/ jcp. 56.1 .12
19. Vitiello L, Masci AM, Montella L, Perna F, Angelini DF, Borsellino G, et al. Thymomaassociated immunodeficiency: a syndrome characterized by severe alterations in NK, T and B-cells and progressive increase in naive CD8+ T cells. Int J Immunopathol Pharmacol (2010) 23:307-16.

Conflict of Interest Statement: The authors declare that the research was conducted in the absence of any commercial or financial relationships that could be construed as a potential conflict of interest.

Received: 08 July 2014; accepted: 16 October 2014; published online: 10 November 2014.

Citation: Martinez B and Browne SK (2014) Good syndrome, bad problem. Front. Oncol. 4:307. doi: 10.3389/fonc.2014.00307

This article was submitted to Thoracic Oncology, a section of the journal Frontiers in Oncology.

Copyright (c) 2014 Martinez and Browne. This is an open-access article distributed under the terms of the Creative Commons Attribution License (CC BY). The use, distribution or reproduction in other forums is permitted, provided the original author(s) or licensor are credited and that the original publication in this journal is cited, in accordance with accepted academic practice. No use, distribution or reproduction is permitted which does not comply with these terms. 